\title{
Inhibitory Effects of Hericium erinaceus Extracts on Melanin Synthesis and Oxidative Stress
}

\author{
Seeun Jeon ${ }^{1}$, Wonjung Hwang ${ }^{2}$, Yoonhee Hong ${ }^{2}$, Mijung Kim ${ }^{3}$, Eunsook Ahn ${ }^{4}$, Seyeon Park ${ }^{5 \star}$ \\ ${ }^{1}$ Department of Biological Engineering, Konkuk University, Seoul, Korea \\ ${ }^{2}$ Department of Cosmetic and Aesthetic, Graduate School of Health Science, Dongduk Women's University, Seoul, Korea \\ ${ }^{3}$ Department of Health and Cosmetics, Dongduk Women's University, Seoul, Korea \\ ${ }^{4}$ Department of Pharmacy, Dongduk Women's University, Seoul, Korea \\ ${ }^{5}$ Department of Applied Chemistry, Dongduk Women's University, Seoul, Korea
}

\section{"Corresponding author: Seyeon Park, Department of Applied Chemistry, Dongduk Women's University, 60 Hwarang-ro, 13-gil, Seongbuk-gu, Seoul 02748, Korea Tel.: +82 29404514 \\ Fax: +82 29404510 \\ Email: sypark21@dongduk.ac.kr}

Received September 1, 2016

Revised October 21, 2016

Accepted October 25, 2016

Published December 30, 2016

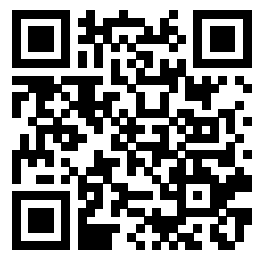

\begin{abstract}
Purpose: The aim of this research is to investigate the effects of Hericium erinaceus $(H$. erinaceus) extracts on melanin synthesis and regulation of oxidative stress. Methods: $H$. erinaceus was extracted with 95\% ethanol and distilled water. The ethanol extracts were further partitioned with distilled water and chloroform. Melanin contents were determined by measuring the absorbance at $450 \mathrm{~nm}$ in B16F1 melanoma cells. MTT assay was performed to check cytotoxicity of $H$. erinaceus extracts on B16F1 and $\mathrm{HaCaT}$ cells. Moreover, $\beta$-catenin/Tcf activity was measured by luciferase assay. The anti-oxidant effects were confirmed by DCFDA expression after TBHP treatment. Results: Wnt3a, a ligand of Wnt signaling pathway, increased $\beta$-catenin signaling and melanin synthesis, while $H$. erinaceus extracts reduced melanin synthesis induced by Wnt3a in B16F1 melanoma cells. $H$. erinaceus extracts also inhibited $\beta$-catenin activity in a dose-dependent manner. In addition, these extracts showed anti-oxidant properties in oxidative stress-induced keratinocytes. $\mathrm{H}$. erinaceus extracts showed little cytotoxicity in melanoma cells and keratinocytes used in this research. Conclusion: $H$. erinaceus extracts might be useful as a safe and effective natural skin-whitening agent.
\end{abstract}

Keywords: Wnt/ß-catenin, Hericium erinaceus, Extracts, Melanoma, Anti-oxidant

\section{Introduction}

피부색은 성별, 연령, 지역, 계절, 신체 부위 또는 건강 상태나 스트레스 등에 따라 변화한다. 피부에는 멜라닌(melanin), 카로틴 (carotene), 헤모글로빈(hemoglobin)이라는 색소가 있는데 그 중 에서도 멜라닌이 피부색의 결정적인 요소이다(quoted in Kim et al., 2004). 멜라닌은 페놀류의 생체 고분자물질로 물이나 대부분 의 유기 용매에 녹지 않으며 멜라노좀(melanosome)에서 합성된 다. 멜라노좀의 특이적 효소인 티로시나아제(tyrosinase)는 티로 신(tyrosine)이 3,4-dihydroxyphenylalanine (DOPA)로, 이어서 DOPA quinone으로 산화하는데 관여하며 최종산물인 indole-5,6dihydroquinone이 바로 멜라닌이다(Kang et al., 2007).

태양광선이 표피의 각질형성세포(케라티노사이트, keratinocyte) 를 자극하면 멜라닌세포자극 호르몬(alpha-melanocyte stimulating hormone, $\alpha-\mathrm{MSH})$ 이 방출되고 멜라닌세포(멜라노 사이트, melanocyte)를 자극하여 멜라닌 생합성을 증가시킨다 (Roméro-Graillet et al., 1997). 멜라닌 합성은 자외선, 사이토카 인(cytokine), 성장인자(growth factor) 및 호르몬 등에 의해 조절 되며 많은 인자들이 관여하는 매우 복잡한 과정으로 세포 내 다양 한 신호전달 기전을 통하여 이루어진다.

멜라닌 생성관련 신호전달 기전은 $\alpha-\mathrm{MSH} /$ melanocortin 1 receptor (MC1R) pathway와 Wnt/ $\beta$-catenin pathway로 알려 져 있다. $\alpha-\mathrm{MSH}$ 가 리간드(ligand)로서 $\mathrm{MC1R}$ 수용체에 결합하 면 cyclic adenosine monophosphate (cAMP)가 생성되고 protein kinase A (PKA)가 자극되면서 microphthalmia-associated transcription factor (MITF) 단백질 발현이 증가한다. 또한 $\mathrm{Wnt}$ 단백질은 Wnt3a 및 다양한 리간드에 의해서 자극이 되는데 $\beta$ - catenin 단백질을 통해서 MITF 전사조절인자를 활성화시키고 멜 


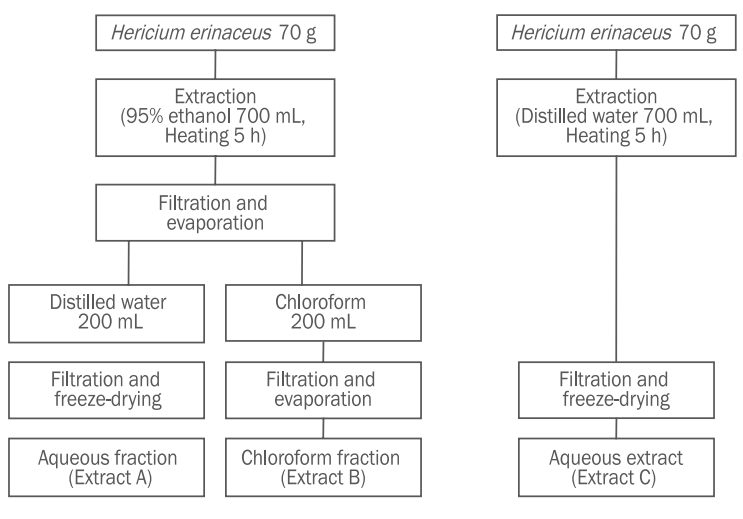

Figure 1. Extraction methods of Hericium erinaceus.

Hericium erinaceus ( $H$. erinaceus) was extracted with $700 \mathrm{~mL}$ of $95 \%$ ethanol for $5 \mathrm{~h}$ in a heating mantle. The ethanol extracts were filtered and concentrated to yield a residue. The residue was suspended in distilled water and partitioned with chloroform. The aqueous and chloroform fractions were designated as extract $\mathrm{A}$ and extract $\mathrm{B}$, respectively. H. erinaceus was also extracted with $700 \mathrm{~mL}$ of distilled water alone for $5 \mathrm{~h}$ in a heating mantle. The aqueous water extract was designated as extract $\mathrm{C}$.

라닌 세포의 분화를 촉진시키는 것으로 알려져 있다(Abdel-Malek et al., 2009; Cho et al., 2009).

멜라닌은 자외선으로부터 피부를 보호하는 기능이 있지만 과도 하게 생성되거나 피부의 기능이 저하되면 피부표면에 침착되어 기 미, 주근깨 등의 미용적인 문제를 발생시킨다. 또한 멜라닌 전구 물질의 독성은 세포변이와 세포사멸을 유발시키기도 한다(Maeda \& Fukuda, 1991; Choi et al., 1998). 한편, 생체 내에서의 생화 학적 산화반응과정에서 발생하는 유해활성산소(reactive oxygen species, ROS)는 멜라닌 합성과정에서 산화를 촉진하여 멜라닌 합성을 증가시키는 것으로 알려져 있다(Lee et al., 2008). 활성 산소에는 일중항산소 $\left({ }^{1} \mathrm{O}_{2}\right)$, hydroxyl radical $(\cdot \mathrm{OH})$ 과 같은 짝짓 지 않은 상태의 free radical, 과산화수소 $\left(\mathrm{H}_{2} \mathrm{O}_{2}\right)$ 등이 있다(Papa \& Skulachev, 1997; Kim et al., 2013).

식물체는 외부자극 및 광합성 과정에서 발생되는 활성산소에 대 한 산화적 손상으로부터 보호할 수 있는 다양한 형태의 항산화 물 질을 생산하는 것으로 알려져 있다. 따라서 천연물의 이러한 항산 화 특성을 이용한 기능성 소재개발에 대한 관심이 높아지고 있으며 건강에 도움이 되는 천연물에 대한 연구들이 활발히 진행되고 있다 (Asano et al., 1994). 그 중에서 버섯은 식용 외에도 약리적인 면에 서 생체방어, 질병회복, 각종 성인병의 예방과 개선에 효과가 있다 (Dragsted et al., 1993). 또한 버섯에는 항산화 물질인 vitamin C 와 vitamin $\mathrm{E}$ 가 많아 암과 세포 노화의 원인인 활성산소를 줄이고 (Hong et al., 2004), $\beta$-D-glucan류는 항암 활성, 항산화 활성, 면 역증강 효과가 있다(Ebihara \& Minamishima, 1984).
노루궁뎅이 버섯(Hericium erinaceus)은 주로 한국, 일본, 중국 등에 분포되어 있으며 균심균류(Hymenomycetidae) 민주름버섯목 (Aphyllophorales) 노루궁뎅이과(Hericiaceae)에 속하는 버섯이다 (National Institute of Agricultural Sciences, 2004). 노루궁뎅이 버섯은 영양학적으로 탄수화물, 단백질, 아미노산, 효소, 무기염류 및 비타민 등이 풍부하고, 항암 및 면역 기능을 증대시키는 효능이 있다(Kabir et al., 1987; Kabir \& Kimura, 1989). 또한 노루궁뎅이 버섯의 성분 중에 치매치료에 효과가 있는 물질이 발견되어 관심이 집중되고 있다(Kawagishi et al., 1996). 그러나 노루궁뎅이 버섯에 대한 기존의 연구는 식용과 약용에 의존하고 있어 항산화, 미백에 관한 연구의 필요성이 요구되는 상황이다.

본 연구에서는 노루궁뎅이 버섯 추출물의 멜라닌 합성 저해능력 과 항산화 능력을 함께 살펴봄으로써 노루궁뎅이 버섯 추출물의 기 능성 화장품 원료로서 가능성을 살펴보고자 하였다. 특히, $\alpha-\mathrm{MSH}$ 와 Wnt signal에 의해 자극되는 멜라닌 합성의 영향을 조사하여 Wnt signal에 의한 멜라닌 합성 신호전달에 미치는 영향을 살펴보았다.

\section{Methods}

\section{1. 재료 및 추출물 제조}

본 연구의 실험재료로 사용한 노루궁뎅이 버섯은 영농조합법인 착한농부들(Korea)에서 구매하였다. 추출물 제조방법은 Figure 1 과 같다. 용매는 $95 \%$ 의 에탄올을 사용하여 heating mantle (MSE104; Misung Scientific, Korea)에서 추출하고 감압 여과한 후 그 용액을 rotavapor (R-114; BÜCHI Labortechnik AG, Switzerland) 에서 농축하였다. 에탄올로 추출하고 증류수와 클로로포름 (chloroform)층으로 분리하여 각각을 농축하고 이를 추출물 A와 추 출물 $\mathrm{B}$ 로 명명하였다. 또 다른 방법으로 증류수만으로 추출하고 동 결 건조하여 추출물 $\mathrm{C}$ 라고 명명하였다.

\section{2. 시약 및 기기}

본 실험에 사용한 주요 시약으로 Dulbecco's modified Eagle' s medium (DMEM)은 WELGENE (Korea), fetal bovine serum (FBS)는 GE Healthcare (UK) 제품을 구매하였고, dual-luciferase reporter assay system은 Promega Corporation (USA) 제품을 이용하였다. Ethanol, chloroform은 국내 일급 시약 제품을 사 용하였다. 주요 기기로는 초임계추출장치(Thar Technologies, USA), centrifuge (Union 32R; Hanil Science Industrial, Korea), $\mathrm{CO}_{2}$ incubator (MCO-175; SANYO Electric, Japan), microplate reader (Synergy HT; BioTek Instruments, USA), spectrophotometer (Zenyth 1100; Anthos Labtec Instruments $\mathrm{GmbH}$, Austria), heating mantle (Misung Scientific), rotavapor (BÜCHI Labortechnik AG)를 사용하였다. 
A

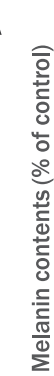

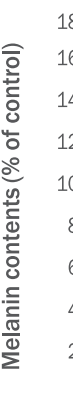

180
160
140
120
100
80
60
40
20
0
$(\mathrm{~mL})$

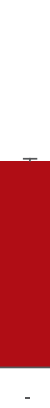

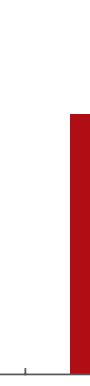

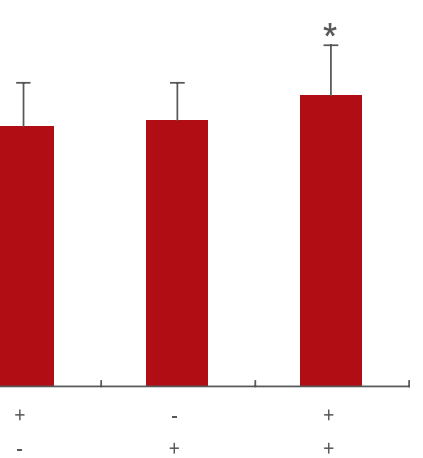

C

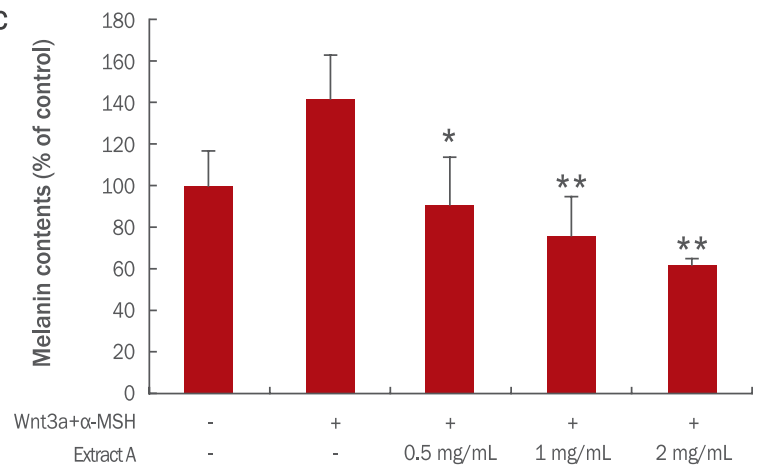

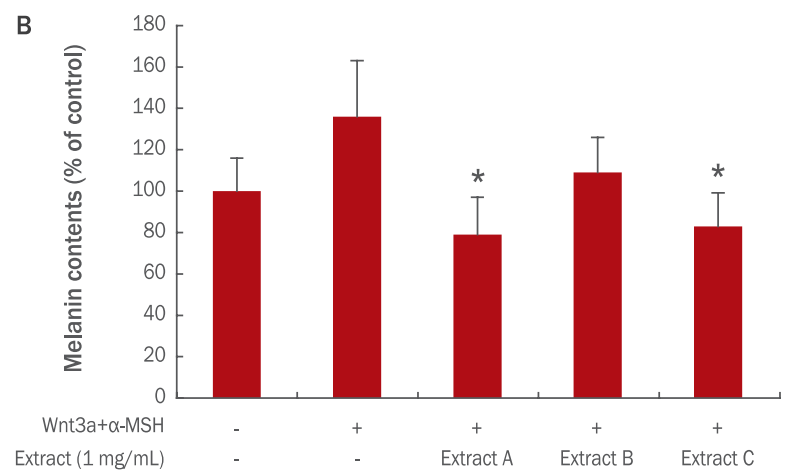

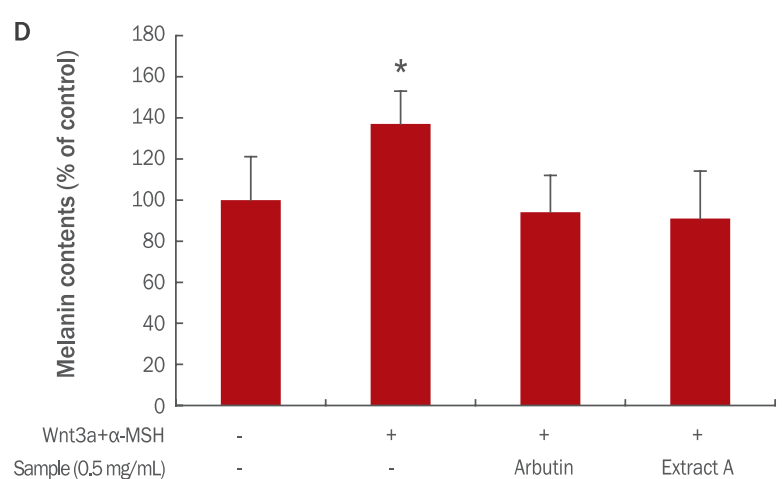

Figure 2. Inhibitory effects of Hericium erinaceus extracts on melanin synthesis.

(A) To investigate the effects of Wnt3a and $\alpha-\mathrm{MSH}$ on melanin synthesis, B16F1 melanoma cells were treated with $1 \mu \mathrm{g} / \mathrm{mL} \mathrm{Wnt} 3 \mathrm{a}$, $100 \mathrm{nM} \alpha-\mathrm{MSH}$, and Wnt3a+ $\alpha-\mathrm{MSH}$. Melanin contents of Wnt3a, $\alpha-\mathrm{MSH}$, and Wnt3a+ $\alpha-\mathrm{MSH}$-treated groups were observed to increase to about 126\%, 129\%, and 141\% compared to the control, respectively. (B) After the treatment with Wnt3a+ $\alpha-M S H$, B16F1 cells were treated with $1 \mathrm{mg} / \mathrm{mL}$ Hericium erinaceus (H. erinaceus) extract A, B, and C to check their effects on Wnt3a+ $\alpha-M S H$ stimulated melanin synthesis. The melanin contents of Wnt3a+ $\alpha$-MSH-treated group increased to $136 \%$, whereas, extract $\mathrm{A}$ and $\mathrm{C}$ decreased melanin contents by $21 \%$ and $17 \%$ compared to the control, respectively. (C) Following Wnt3a+ $\alpha-M S H$ treatment, B16F1 cells were incubated with $\mathrm{H}$. erinaceus extract A. The melanin contents of Wnt3a+ $\alpha-\mathrm{MSH}$-treated group increased to $142 \%$. The extract A decreased melanin synthesis in a dose-dependent manner. $0.5,1$, and $2 \mathrm{mg} / \mathrm{mL}$ of extract A decreased melanin contents by $9 \%, 24 \%$, and $38 \%$ compared to the control, respectively. (D) After Wnt3a+ $\alpha-M S H$ treatment, B16F1 cells were treated with $0.5 \mathrm{mg} / \mathrm{mL}$ arbutin, an inhibitor of melanin synthesis, and $0.5 \mathrm{mg} / \mathrm{mL} \mathrm{H}$. erinaceus extract A. The melanin contents of Wnt3a+ $\alpha-M S H$-treated group increased to $137 \%$. Both, arbutin and extract A decreased melanin contents by $6 \%$ and $9 \%$ compared to the control, respectively. Values represent the mean \pm standard deviation of three independent experiments. The Student's t-test was performed to determine statistical significance $\left({ }^{*} p<.05\right.$, $\left.{ }^{* *} p<.01\right)$.

\section{3. 세포배양}

본 실험에서 사용한 각질형성세포주(HaCaT cell), 멜라노마세포 주(B16F1 melanoma cell), $\beta$-catenin 과발현세포주(SW480 cell) 는 한국세포주은행(Korean Cell Line Bank, Korea)에서 구입하여 사용하였다. 세포배양은 DMEM에 FBS $10 \%$ 와 항생제 $1 \%$ 를 넣어 $37^{\circ} \mathrm{C}$ 와 $5 \% \mathrm{CO}_{2}$ 조건의 세포배양기에서 배양하였다.

\section{4. 세포에서 멜라닌 색소의 측정}

6-well plate에 $\mathrm{B} 16 \mathrm{~F} 1$ melanoma cell을 $1 \times 10^{5}$ cells/well로 분 주하여 세포배양기에 배양하였다. $1 \mu \mathrm{g} / \mathrm{mL}$ 농도의 Wnt3a와 100 $\mathrm{nM}$ 농도의 $\alpha-\mathrm{MSH}$ 를 처리하여 $24 \mathrm{~h}$ 동안 추가 배양하였다. 배지 를 제거한 후 차가운 phosphate buffered saline (PBS)으로 2 회 세
척하고 trypsin-ethylenediaminetetraacetic acid를 처리한 후 세포를 모았다. $12,000 \mathrm{rpm}$ 에서 $20 \mathrm{~min}$ 동안 원심분리하여 상층 액을 제거한 후 pellet만 남기고 $100 \mu \mathrm{L}$ radioimmunoprecipitation assay buffer (RIPA buffer)를 넣었다. 얼음 위에서 $30 \mathrm{~min}$ 동안 용 해시킨 후 $13,000 \mathrm{rpm}$ 에서 $30 \mathrm{~min}$ 동안 원심분리하였다. 분리된 멜라닌 색소를 $2 \mathrm{~N}$ sodium hydroxide $[\mathrm{NaOH}$; dissolved in $20 \%$ dimethyl sulfoxide (DMSO)], $60^{\circ} \mathrm{C}$ 에서 녹인 후 $450 \mathrm{~nm}$ 에서 흡광 도를 측정하였다. 생성된 멜라닌 양을 대조군에 대한 상대값으로 산출하여 정량하였다.

\section{MTT assay}

96-well plate에 세포들을 $4 \times 10^{3}$ cells/well로 분주하여 $37^{\circ} \mathrm{C}$, 


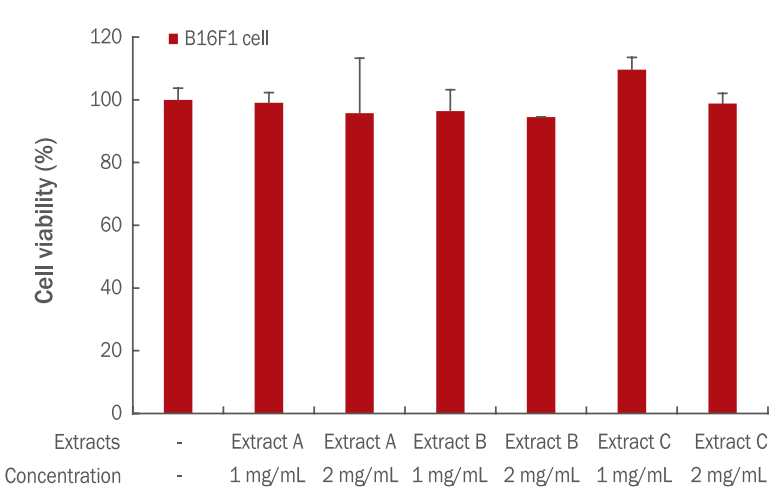

Figure 3. Effects of Hericium erinaceus extract A, B, and C on B16F1 cell viability.

Cytotoxicity of Hericium erinaceus ( $H$. erinaceus) extracts was investigated by MTT assay. B16F1 cells were treated with $H$. erinaceus extract $A, B$, and $C$ at concentrations of 1 and $2 \mathrm{mg} / \mathrm{mL}$. None of the extracts showed any cytotoxicity. Cell viability was expressed as a percentage of control. Values represent the mean \pm standard deviation of three independent experiments.

$5 \% \mathrm{CO}_{2}$ 조건의 세포배양기에서 배양시켰다. 세포들 중에 $\mathrm{B} 16 \mathrm{~F} 1$ cell은 멜라닌 합성 저해효과에 대해서, HaCaT cell은 항산화 효과 를 위해 배양하였다. 노루궁뎅이 버섯 추출물들은 각각 $1,2 \mathrm{mg} /$ $\mathrm{mL}$ 의 농도로 처리하여 $24 \mathrm{~h}$ 동안 세포배양기에서 배양하였다. MTT 시약을 $20 \mu \mathrm{L}$ 씩 첨가하고 $3 \mathrm{~h}$ 후 형성된 formazan을 $\mathrm{DMSO}$ 로 녹인 후 microplate reader로 $492 \mathrm{~nm}$ 에서 흡광도를 측정하여 세포의 생존율을 측정하였다.

\section{6. $\beta$-Catenin 활성 저해 효과(Luciferase assay)}

$\beta$-Catenin이 과발현된 SW480 cell을 이용하여 노루궁뎅이 버 섯 추출물들이 $\beta$-catenin/T cell factor (Tcf) signaling에 미치는 영 향을 측정하였다. 96-well plate에 SW480 cell을 분주하고 $24 \mathrm{~h}$ 후 TOP-flash reporter, FOP-flash reporter가 발현되는 vector로 형 질전환 시켰다. $0.10 \mu \mathrm{g}$ TOP flash와 $0.10 \mu \mathrm{g}$ FOP flash luciferase reporter로 형질전환 된 SW480 cell에 추출물 A, B를 $0.5,1,2,5$, $10 \mathrm{mg} / \mathrm{mL}$ 농도로 처리하였다. $24 \mathrm{~h}$ 동안 노출시킨 후, luciferase assay system에서 제공되는 프로토콜에 따라 lysis buffer를 처리 하여 luciferase 활성도를 측정하였다. 측정한 값을 TOP control과 비교하여 상대적인 저해 효과를 나타내었다.

\section{7. 노루궁뎅이 버섯 추출물의 항산화 효과 측정}

96-well plate에 HaCaT cell을 $1.5 \times 10^{4}$ cells/well로 분주한 후 $37^{\circ} \mathrm{C}, 5 \% \mathrm{CO}_{2}$ 조건의 세포배양기에 배양하였다. $24 \mathrm{~h}$ 배양 후, $50 \mu \mathrm{M}$ tert-butyl hydroperoxide (TBHP)를 $1 \mathrm{~h}$ 처리한 후, PBS 로 2회 세척하고 배양된 세포에 phenol red가 없는 DMEM에 녹 인 노루궁뎅이 버섯 추출물들을 $0.5,1 \mathrm{mg} / \mathrm{mL}$ 처리하고 $24 \mathrm{~h}$ 동

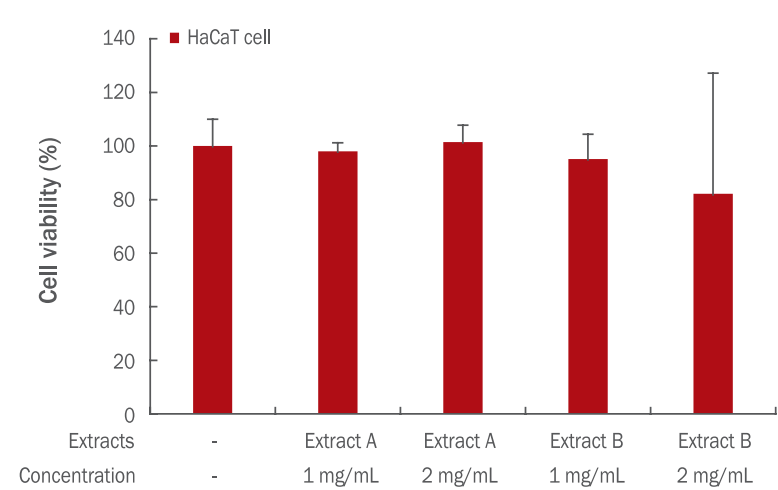

Figure 4. Effects of Hericium erinaceus extract A and B on HaCaT cell viability.

Cytotoxicity of Hericium erinaceus ( $H$. erinaceus) extracts was investigated by MTT assay. HaCaT cells were treated with $H$. erinaceus extract $A$ and $B$ at concentrations of 1 and $2 \mathrm{mg} / \mathrm{mL}$. Extract A showed no cytotoxicity, however, marginal cytotoxicity was observed with $2 \mathrm{mg} / \mathrm{mL}$ of extract B. Cell viability was expressed as a percentage of control. Values represent the mean \pm standard deviation of three independent experiments.

안 세포배양기에 배양하였다. 배양 후 PBS로 2회 세척하고 $25 \mu \mathrm{M}$ dichlorofluorescin diacetate (DCFDA) 시약을 $45 \mathrm{~min}$ 처리 한 후 microplate reader를 이용하여 485/528 nm에서 형광을 측정하였다.

\section{8. 형광현미경을 이용한 항산화 효과 관찰}

6-well plate에 cover glass를 넣고 $\mathrm{HaCaT}$ cell을 $1.5 \times 10^{4}$ cells/ well로 분주하였다. 배양 후, $50 \mu \mathrm{M} \mathrm{TBHP}$ 을 $1 \mathrm{~h}$ 동안 처리한 후 $2 \mathrm{~mL} \mathrm{PBS}$ 로 세척하고, 추출물 $\mathrm{A}, \mathrm{B}$ 를 각각 $1 \mathrm{mg} / \mathrm{mL}$ 농도로 처 리하였다. 세포배양기에서 $24 \mathrm{~h}$ 경과한 후 DCFDA를 $45 \mathrm{~min}$ 동 안 처리하고 $3 \%$ paraformaldehyde를 포함한 $\mathrm{PBS}$ 를 $1 \mathrm{~mL}$ 첨가 한 후 $15 \mathrm{~min}$ 동안 상온에 두었다. PBS에 $0.25 \%$ triton X-100을 혼합한 후 $1 \mathrm{~mL}$ 씩 넣고 $5 \mathrm{~min}$ 동안 상온에 두었다. 차가운 $2 \mathrm{~mL}$ $\mathrm{PBS}$ 로 세척하고 $\mathrm{PBS}$ 가 있는 상태에서 $5 \mathrm{~min}$ 동안 상온에서 두 는 것을 2 회 반복했다. $10 \mathrm{~mL} \mathrm{PBS}$ 와 $0.3 \mu \mathrm{L} \mathrm{4,6-diamidino-2-}$ phenylindole (DAPI)가 혼합된 용액을 $1 \mathrm{~mL}$ 씩 각각 첨가하여 은박 지로 포장 후 $5 \mathrm{~min}$ 동안 흔들어 섞어주었고 $2 \mathrm{~mL} \mathrm{PBS를} \mathrm{첨가하}$ 여 3회 세척했다. Cover glass를 꺼내 슬라이드 글라스에 밀착시킨 후 형광현미경을 관찰하였다.

\section{9. 통계처리}

본 연구는 모두 3 회 이상 수행하여 표와 그래프의 수치를 각 실 험 횟수에 대한 평균과 표준편차로 나타내었다. 각 sample의 통 계적 유의성에 대한 분석을 Student's t-test 방법으로 검증하였고, $p<.05\left({ }^{*} p<.05,{ }^{* *} p<.01\right)$ 인 값에 대하여 유의미한 것으로 판정하였다. 


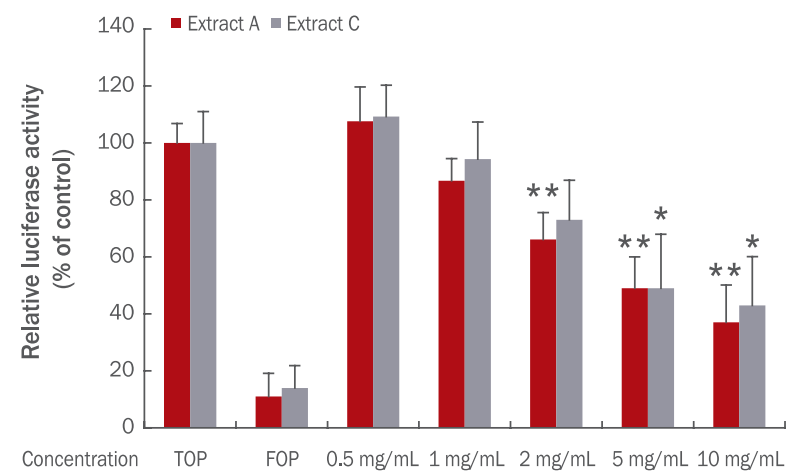

Figure 5. Inhibitory effects of Hericium erinaceus extract A and C on $\beta$-catenin/Tcf activity.

SW480 cells were treated with $0.5,1,2,5$, and $10 \mathrm{mg} / \mathrm{mL}$ of Hericium erinaceus extract $A$ and $C$ after transfection with TOPand FOP-flash luciferase reporter. The $\beta$-catenin/Tcf activities showed decrease in a dose-dependent manner from $1 \mathrm{mg} /$ $\mathrm{mL}$ to $10 \mathrm{mg} / \mathrm{mL}$. Values represent the mean \pm standard deviation of three independent experiments $\left({ }^{*} p<.05\right.$, $\left.{ }^{* *} p<.01\right)$.

\section{Results and Discussion}

\section{1. 노루궁뎅이 버섯 추출물의 멜라닌 합성 저해능 측정}

$\mathrm{Wnt} 3 \mathrm{a}$ 와 $\alpha-\mathrm{MSH}$ 가 멜라닌 합성에 미치는 영향을 확인하기 위 하여 B16F1 melanoma cell에 Wnt3a $(1 \mu \mathrm{g} / \mathrm{mL}), \alpha-\mathrm{MSH}(100 \mathrm{nM})$ 및 $\mathrm{Wnt} 3 \mathrm{a}+\alpha-\mathrm{MSH}$ 를 처리하고 $450 \mathrm{~nm}$ 에서 멜라닌 합성량을 확 인하였다(Figure $2 \mathrm{~A}$ ). Wnt3a, $\alpha-\mathrm{MSH}$ 및 Wnt3a+ $\alpha-\mathrm{MSH}$ 처리군 은 아무것도 처리하지 않은 대조군에 비해 각각 $126 \%, 129 \%, 141 \%$ 정도로 멜라닌 합성량이 증가하였다. 따라서 Wnt3a와 $\alpha-\mathrm{MSH}$ 는 모두 $\mathrm{B} 16 \mathrm{~F} 1$ melanoma cell에서 멜라닌 합성을 증진시키는 것으로 판단된다.

Figure $2 \mathrm{~A}$ 의 결과를 바탕으로, 멜라닌 합성량이 가장 높게 나타 난 Wnt3a+ $\alpha-\mathrm{MSH}$ 을 처리한 후 노루궁뎅이 버섯 에탄올 추출 후 수용액층(이하 추출물 $\mathrm{A}$ )과 노루궁뎅이 버섯 에탄올 추출 후 클로 로포름층(이하 추출물 $\mathrm{B})$, 노루궁뎅이 버섯 물 추출(이하 추출물 $\mathrm{C})$ 을 각각 $1 \mathrm{mg} / \mathrm{mL}$ 씩 처리하여 멜라닌 양을 측정하였다(Figure 2B). Wnt3a $+\alpha-\mathrm{MSH}$ 처리군은 대조군에 비해 $136 \%$ 정도 멜라닌 합성이 증가한 반면, 추출물 $\mathrm{A}$ 처리군과 추출물 $\mathrm{C}$ 처리군은 대조군 에 비해 각각 $21 \%, 17 \%$ 감소하여 멜라닌 합성이 유의미하게 저해 되는 것을 관찰할 수 있었다 $(p<.05)$. 이것으로 추출물 $\mathrm{A}$ 처리군과 추출물 $\mathrm{C}$ 처리군 모두 멜라닌 합성에 대하여 저해하는 능력이 있다 는 것을 알 수 있다.

Wnt3a와 $\alpha-\mathrm{MSH}$ 를 동시에 처리한 $\mathrm{B} 16 \mathrm{~F} 1$ cell에서 멜라닌 합 성 저해능이 가장 높은 추출물 $\mathrm{A}$ 의 농도별 효과를 확인한 결과, $\mathrm{Wnt} 3 \mathrm{a}+\alpha-\mathrm{MSH}$ 처리군은 대조군에 비해 멜라닌 합성이 $142 \%$ 증 가하였으나 추출물 $\mathrm{A}$ 처리군들은 농도에 비례하여 멜라닌 합성을
저해시켰다(Figure $2 \mathrm{C}$ ). 추출물 A $0.5 \mathrm{mg} / \mathrm{mL}$ 처리군은 멜라닌 합 성량이 대조군에 비해 $9 \%(p<.05)$ 감소한 반면, 추출물 $\mathrm{A}$ 의 $1 \mathrm{mg} /$ $\mathrm{mL}, 2 \mathrm{mg} / \mathrm{mL}$ 처리군은 각각 $24 \%, 38 \%$ ( $p$ <.01) 감소하였다. 이것 을 통해 추출물의 농도가 증가할수록 멜라닌 저해능력도 유의미하 게 커지는 것을 알 수 있었다.

멜라닌 합성 억제제인 arbutin과 노루궁뎅이 버섯 추출물 중 효 과가 높은 것으로 나타난 추출물 $\mathrm{A}$ 의 멜라닌 합성 저해능을 비교 하였다(Figure 2D). B16F1 cell에 Wnt3a와 $\alpha-\mathrm{MSH}$ 를 처리한 후 arbutin $0.5 \mathrm{mg} / \mathrm{mL}$ 과 추출물 A $0.5 \mathrm{mg} / \mathrm{mL}$ 을 각각 처리하고 멜 라닌 양을 측정한 결과, 대조군에 비해 Wnt3a+ $\alpha-\mathrm{MSH}$ 처리군은 멜라닌 합성이 $137 \%$ 증가한 반면, arbutin군과 추출물 A 처리군은 각각 $6 \%, 9 \%$ 감소하여, 멜라닌 합성을 유사하게 저해시켰다. 따라 서 추출물 $\mathrm{A}$ 는 arbutin과 유사한 멜라닌 합성 억제 효과를 가지고 있음을 알 수 있었다.

\section{2. 노루궁뎅이 버섯 추출물의 세포 독성 측정}

노루궁뎅이 버섯 추출물의 세포 독성을 확인하기 위해서 $\mathrm{B} 16 \mathrm{~F} 1$ cell과 $\mathrm{HaCaT}$ cell에 노루궁뎅이 버섯 추출물들을 각각 $1,2 \mathrm{mg} /$ $\mathrm{mL}$ 의 농도로 처리하고 MTT assay를 수행하였다(Figure 3, 4). 그 결과 $\mathrm{B} 16 \mathrm{~F} 1$ cell에 처리된 노루궁뎅이 추출물 $\mathrm{A}$ 처리군 $(1,2 \mathrm{mg} /$ $\mathrm{mL})$ 의 세포 생존율은 $99 \%, 96 \%$ 로 나타났고, 추출물 B 처리군(1, $2 \mathrm{mg} / \mathrm{mL})$ 은 $96 \%, 94 \%$ 의 생존율이 나타났으며 추출물 C 처리군 (1, $2 \mathrm{mg} / \mathrm{mL})$ 은 $109 \%, 98 \%$ 의 생존율을 보였다. 한편, HaCaT cell 에서는 노루궁뎅이 버섯 추출물 $\mathrm{A}$ 처리군 $(1,2 \mathrm{mg} / \mathrm{mL})$ 의 세포 생 존율은 $97 \%, 101 \%$ 로 나타났으며, 추출물 B 처리군 $(1,2 \mathrm{mg} / \mathrm{mL})$ 에 서는 $95 \%, 82 \%$ 의 생존율을 확인할 수 있었다. 따라서 멜라닌 합성 저해능과 항산화 효과의 측정을 위한 노루궁뎅이 버섯 추출물 1,2 $\mathrm{mg} / \mathrm{mL}$ 의 농도는 세포 독성이 크지 않은 것으로 생각된다.

\section{3. 노루궁뎅이 버섯 추출물 $A$ 와 추출물 $C$ 의 농도별 $\beta-$ - catenin/ $\mathrm{Tcf}$ 활성도 저해 효과 측정}

SW480 cell을 TOP flash와 FOP flash luciferase reporter로 형 질전환하고 노루궁뎅이 버섯 추출물 $\mathrm{A}$ 와 추출물 $\mathrm{C}$ 를 $0.5,1,2,5$, $10 \mathrm{mg} / \mathrm{mL}$ 의 농도로 처리하였다. $24 \mathrm{~h}$ 동안 배양한 후 활성도를 측 정하여 $\mathrm{TOP} / \mathrm{FOP}$ control과 비교하여 상대적인 저해 효과를 살펴보 았다(Figure 5). 그 결과 노루궁뎅이 버섯 추출물 A, C 모두 $1 \mathrm{mg} /$ $\mathrm{mL}$ 이상에서 농도의존적으로 $\beta$-catenin 활성을 저해시키는 것으로 나타났다. 특히, $2 \mathrm{mg} / \mathrm{mL}$ 이상에서는 추출물 $\mathrm{A}$ 와 추출물 $\mathrm{C}$ 가 유 의한 저해 효과를 보였다 $(p<.05, p<.01)$. 따라서 노루궁뎅이 버섯 추 출물이 $\beta$-catenin 활성 저해를 통한 멜라노사이트 분화 억제효과를 가져오는 것으로 생각된다. 이는 Kim et al. (2014)의 연구에서 청미 래넝굴 추출물이 농도의존적으로 $\beta$-catenin의 활성을 저해하면서 멜라닌 합성을 저해한다는 결과와 유사하며 노루궁뎅이 버섯 추출 물이 미백화장품의 재료로 사용될 수 있다는 가능성을 시사한다. 


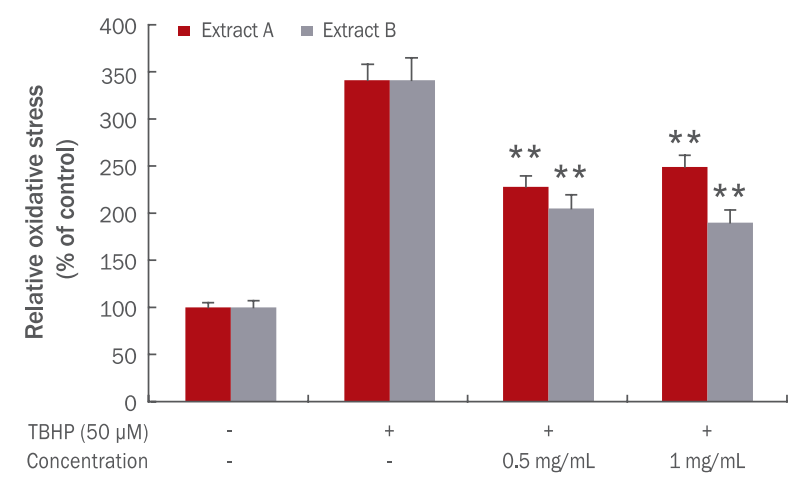

Figure 6. Anti-oxidant effects of Hericium erinaceus extract A and $B$.

After induction of ROS with treatment of TBHP, HaCaT cells were treated with Hericium erinaceus $(H$. erinaceus) extracts. Relative oxidative stress level of TBHP-treated group was very high compared to the controls. $H$. erinaceus extract $A$ and $B$ $(0.5$ and $1 \mathrm{mg} / \mathrm{mL}$ ) decreased oxidative stress in TBHP-treated cells. Values represent the mean \pm standard deviation of three independent experiments $\left({ }^{* *} p<.01\right)$.

\section{4. 노루궁뎅이 버섯 추출물의 농도별 항산화 효과 측정}

항산화 물질이 버섯의 영양 성분에 많은 것으로 보고되었기 에 노루궁뎅이 버섯 추출물에 대해서 항산화 효과를 살펴보았다. $\mathrm{HaCaT}$ cell에 세포에서 활성산소를 증가시키는 물질인 TBHP를 처리하여 산화 스트레스를 증가시킨 후 노루궁뎅이 버섯 추출물을 처리하여 형광을 측정하였다. 노루궁뎅이 추출물은 $0.5,1 \mathrm{mg} / \mathrm{mL}$ 씩 각각 처리하고 DCFDA 시약을 처리한 후 485/528 nm에서 산화 스트레스를 측정하였다(Figure 6). 그 결과 TBHP 처리군은 대조군 에 비해 산화 스트레스가 높게 나타났으나 노루궁뎅이 버섯 추출물 $\mathrm{A}$ 처리군과 추출물 $\mathrm{B}$ 처리군은 $\mathrm{TBHP}$ 군과 비교하여 유의적으로 산화 스트레스가 감소하였다. 이를 통해 노루궁뎅이 버섯 추출물이 항산화 효과가 있음을 알 수 있었다( $p<.01)$.

\section{5. 형광현미경을 이용한 항산화 효과 관찰}

$\mathrm{HaCaT}$ cell에 대한 항산화 실험에서 수치적으로 효과가 나타났 기에 활성산소량을 시각적으로 확인하기 위해 형광현미경으로 관 찰하였다(Figure 7). $\mathrm{DCFDA}$ 를 처리하여 cell에 활성산소가 있는지 를 형광현미경으로 확인한 결과, 대조군은 DAPI만 염색된 상태가 관찰되었고(Figure $7 \mathrm{~A}$ ), TBHP군은 DCFDA의 형광물질이 많이 나 타나 활성산소가 증가한 것을 알 수 있었다(Figure 7B). 한편, 노루 궁뎅이 버섯 추출물 $\mathrm{A}, \mathrm{B} 1 \mathrm{mg} / \mathrm{mL}$ 처리군은 다소 약한 형광이 나 타나 TBHP군에 비해 활성산소가 감소한 것을 알 수 있었다(Figure $7 \mathrm{C}, 7 \mathrm{D})$. 이는 노루궁뎅이 버섯 추출물이 활성산소에 대하여 항산 화 효과를 가진다는 것을 의미한다.
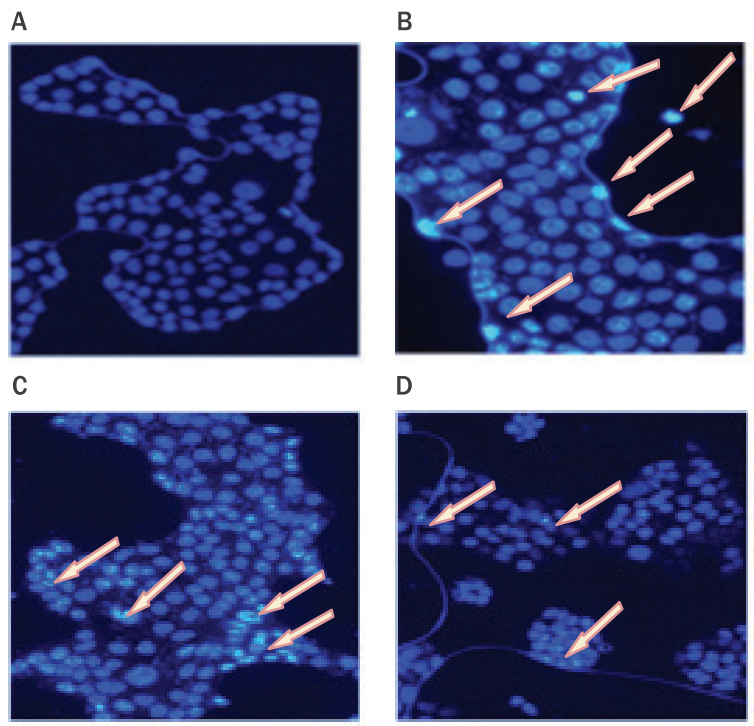

D

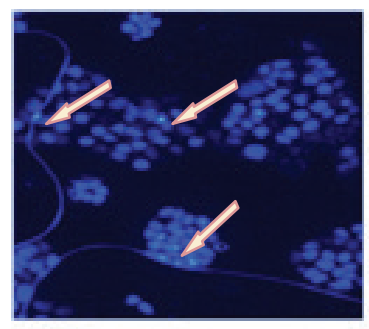

Figure 7. Anti-oxidant effects of Hericium erinaceus extract A and $B$ confirmed by a fluorescence microscopy.

After TBHP treatment, HaCaT cells were treated with Hericium erinaceus ( $H$. erinaceus) extract A and B. Fluorescence staining was conducted to get the visual estimation of anti-oxidant properties of extracts. (A) Control group (HaCaT cells without TBHP treatment) showed no DCFDA fluorescence. (B) TBHP group showed very high levels of DCFDA fluorescence. (C) $1 \mathrm{mg} /$ $\mathrm{mL} H$. erinaceus extract $A$ treated group showed slight DCFDA fluorescence compared to TBHP group. (D) $1 \mathrm{mg} / \mathrm{mL} H$. erinaceus extract $\mathrm{B}$ group showed slight DCFDA fluorescence compared to TBHP group. The arrows indicate DCFDA fluorescence.

\section{Conclusion}

본 논문에서는 노루궁뎅이 버섯의 성분을 추출하여 항산화 및 미백용 소재로서의 효능 및 개발 가능성을 확인하였다.

$1 \mu \mathrm{g} / \mathrm{mL}$ Wnt3a와 $100 \mathrm{nM} \alpha-\mathrm{MSH}$ 를 각각 또는 함께 처리하였 을 때 모두 멜라노사이트에서 멜라닌 합성을 증진시키는 것으로 나 타났으며, 추출방법과 상관없이 노루궁뎅이 버섯 추출물 $\mathrm{A}$ 와 추출 물 $\mathrm{C}$ 를 처리한 군들에서 멜라닌 합성 저해가 유의하게 나타났다. Wnt3a와 $\alpha-\mathrm{MSH}$ 를 처리한 후 $\mathrm{B} 16 \mathrm{~F} 1$ melanoma cell에 대해 추출 물 $\mathrm{A}$ 를 $0.5,1,2 \mathrm{mg} / \mathrm{mL}$ 각각의 농도로 처리하여 멜라닌 합성 저 해능을 살펴본 결과 멜라닌 합성이 농도의존적으로 감소하였다. 또한, Wnt3a와 $\alpha-\mathrm{MSH}$ 를 처리한 $\mathrm{B} 16 \mathrm{~F} 1$ cell에 추출물 $\mathrm{A} 0.5 \mathrm{mg} /$ $\mathrm{mL}$ 와 arbutin $0.5 \mathrm{mg} / \mathrm{mL}$ 를 처리한 결과, 추출물 $\mathrm{A}$ 가 arbutin과 유사하게 멜라닌 합성을 저해시켰다.

노루궁뎅이 버섯 추출물의 세포독성을 확인하기 위해 $\mathrm{B} 16 \mathrm{~F} 1$ melanoma cell과 $\mathrm{HaCaT}$ cell에서 세포 생존율을 조사한 결과, 추 출물 $\mathrm{A}$, 추출물 $\mathrm{B}$ 및 추출물 $\mathrm{C}$ 는 모두 세포 독성이 크지 않은 것으 로 나타났다. 한편, SW480 cell에 추출물 A와 추출물 C를 $0.5,1,2$, $5,10 \mathrm{mg} / \mathrm{mL}$ 의 농도로 처리하여 농도별 $\beta$-catenin/ $\mathrm{Tcf}$ 활성 저해 
효과를 살펴보니 $1 \mathrm{mg} / \mathrm{mL}$ 이상에서 농도의존적으로 $\beta$-catenin 활성을 저해하는 것으로 나타났다. 이를 통해 노루궁뎅이 버섯 추 출물이 $\beta$-catenin 활성 저해를 통하여 멜라노사이트 분화 억제 효 과를 가져 오는 것으로 생각할 수 있다.

$\mathrm{HaCaT}$ cell에 활성산소를 증가시키는 TBHP를 처리한 후 노루 궁뎅이 버섯 추출물을 처리하여 형광발현 정도를 살펴본 결과, 노 루궁뎅이 버섯 추출물 $\mathrm{A}$ 처리군과 추출물 $\mathrm{B}$ 처리군은 $\mathrm{TBHP}$ 군과 비교하여 산화 스트레스가 감소함을 확인하였다. 이를 통해 노루궁 뎅이 버섯 추출물이 항산화 효과가 있음을 알 수 있었다.

따라서 노루궁뎅이 버섯 추출물들이 미백기능성 및 항산화 화장 품 소재로서의 가능성이 있을 것으로 사료된다.

\section{References}

Abdel-Malek ZA, Ruwe A, Kavanagh-Starner R, Kadekaro AL, Swope V, Haskell-Luevano C, Koikov L, Knittel JJ. alphaMSH tripeptide analogs activate the melanocortin 1 receptor and reduce UV-induced DNA damage in human melanocytes. Pigment Cell and Melanoma Research, 22: 635-644, 2009.

Asano N, Tomioka E, Kizu H, Matsui K. Sugars with nitrogen in the ring isolated from the leaves of Morus bombycis. Carbohydrate Research, 253: 235-245, 1994.

Cho M, Ryu M, Jeong Y, Chung YH, Kim DE, Cho HS, Kang S, Han JS, Chang MY, Lee CK, et al. Cardamonin suppresses melanogenesis by inhibition of Wnt/betacatenin signaling. Biochemical and Biophysical Research Communications, 390: 500-505, 2009.

Choi BW, Lee BH, Kang KJ, Lee ES, Lee NH. Screening of the tyrosinase inhibitors from marine algae and medicinal plants. Korean Journal of Pharmacognosy, 29: 237-242, 1998.

Dragsted LO, Strube M, Larsen JC. Cancer-protective factors in fruits and vegetables: biochemical and biological background. Pharmacology and Toxicology, 72: 116-135, 1993.

Ebihara K, Minamishima Y. Protective effect of biological response modifiers on murine cytomegalovirus infection. Journal of Virology, 51: 117-122, 1984.

Hong KH, Kim BY, Kim HK. Analysis of nutritional components in Pleurotus ferulea. Korean Journal of Food Science and Technology, 36: 563-567, 2004.

Kabir Y, Kimura S. Dietary mushrooms reduce blood pressure in spontaneously hypertensive rats (SHR). Journal of Nutritional Science and Vitaminology, 35: 91-94, 1989.

Kabir Y, Yamaguchi M, Kimura S. Effect of shiitake (Lentinus edodes) and maitake (Grifola frondosa) mushrooms on blood pressure and plasma lipids of spontaneously hypertensive rats. Journal of Nutritional Science and Vitaminology, 33: 341-346, 1987.

Kang WK, Hwang SD, Kim HS, Jeung JS, Lee BU. The development of whitening cosmetic ingredient having activity of melanin degradation. Korean Society for Biotechnology and Bioengineering Journal, 22: 7-15, 2007.

Kawagishi H, Shimada A, Hosokawa S, Mori H, Sakamoto H, Ishiguro Y, Sakemi S, Bordner J, Kojima N, Furukawa S. Erinacines E, F, and G, stimulators of nerve growth factor (NGF)-synthesis, from the mycelia of Hericium erinaceum. Tetrahedron Letters, 37: 7399-7402, 1996.

Kim DH, Park SR, Debnath T, Hasnat MA, Pervin M, Lim BO. Evaluation of the antioxidant activity and antiinflammatory effect of Hericium erinaceus water extracts. Korean Journal of Medicinal Crop Science, 21: 112-117, 2013.

Kim JD, Kim SJ, Kim HS, Park GH, Lee HS, Jin JE. New cosmetology. Donghwa Publishing, Paju, pp40-44, 2004. (Mitsui T. 1997.)

Kim YE, Park SY, Choe TB. Inhibition of melanogenesis by Smilax china L. superchritical extract. Journal of the Korean Society of Cosmetology, 20: 707-712, 2014.

Lee HJ, Kim HS, Park YJ, Kim JS, Moon C, Kim JC, Bae CS, Jo SK, Kim SH. The effect of Bu-Zhong-Yi-Qi-Tang on epidermal melanocytes in ultraviolet B-irradiated mice. Journal of Radiation Protection, 33: 87-91, 2008.

Maeda K, Fukuda M. In vitro effectiveness of several whitening cosmetic components in human melanocytes. Journal of the Society of Cosmetic Chemists, 42: 361-368, 1991.

National Institute of Agricultural Sciences. The mushrooms of Korea. Dongbang Media, Seoul, pp264-265, 2004.

Papa S, Skulachev VP. Reactive oxygen species, mitochondria, apoptosis and aging. Molecular and Cellular Biochemistry, 174: 305-319, 1997.

Roméro-Graillet C, Aberdam E, Clément M, Ortonne JP, Ballotti R. Nitric oxide produced by ultraviolet-irradiated keratinocytes stimulates melanogenesis. The Journal of Clinical Investigation, 99: 635-642, 1997. 


\section{국문초록}

\section{노루궁뎅이 버섯 추출물의 멜라닌 생성 억제 및 항산화 효과}

전세은 ${ }^{1}$, 황원정 ${ }^{2}$, 홍윤희 ${ }^{2}$, 김미정 ${ }^{3}$, 안은숙 ${ }^{4}$, 박세연 $^{5 *}$

${ }^{1}$ 건국대학교 생물공학과, 서울, 한국

${ }^{2}$ 동덕여자대학교 보건과학대학원 향장에스테틱과, 서울, 한국

${ }^{3}$ 동덕여자대학교 보건향장학과, 서울, 한국

${ }^{4}$ 동덕여자대학교 약학과, 서울, 한국

${ }^{5}$ 동덕여자대학교 응용화학과, 서울, 한국

목적: 본 연구는 노루궁뎅이 버섯 추출물의 멜라닌 합성 및 산화 스트레스 조절에 미치는 영향을 조사하는데 그 목적이 있다. 방법: 노루궁뎅이 버섯은 각각 $95 \%$ 에탄올과 증류수로 추출하였고, 에탄올 추출물은 다시 증류수와 클로로포름으로 분획하였 다. 멜라닌 합성량은 $\mathrm{B} 16 \mathrm{~F} 1$ 세포를 통해 확인하였고, 노루궁뎅이 버섯 추출물의 세포 독성은 $\mathrm{B} 16 \mathrm{~F} 1$ 세포와 $\mathrm{HaCaT}$ 세포를 통해 MTT assay 방법으로 확인하였다. 또한, $\beta$-catenin/Tcf 활성은 luciferase assay를 통해 측정하였다. 항산화 효과는 TBHP 처리 후 DCFDA 발현정도로 확인하였다. 결과: Wnt 신호전달기전의 리간드인 Wnt3a는 $\beta$-catenin의 신호전달 및 멜라닌 합성을 증 가시키는 반면, 노루궁뎅이 버섯 추출물은 Wnt3a에 의해 유도된 멜라닌 합성을 감소시켰다. 또한, 노루궁뎅이 버섯 추출물은 농 도의존적으로 $\beta-$ catenin 활성도를 억제하였고, 산화 스트레스가 유도된 케라티노사이트에서의 항산화 효과를 나타내었다. 그리 고 본 연구에서 사용된 케라티노사이트와 멜라노마 세포에서의 세포 독성은 크지 않은 것으로 나타났다. 결론: 노루궁뎅이 버섯 추출물은 미백기능성 및 항산화 화장품 소재로서의 가능성이 있을 것으로 사료된다.

핵심어: Wnt/ $\beta$-catenin, 노루궁뎅이 버섯, 추출물, 멜라노마, 항산화

\section{참고문헌}

국립농업과학원. 한국의 버섯: 식용버섯과 독버섯. 동방미디어, 서울, pp264-265, 2004.

김다혜, 박사라, 트리쉬나, 하스낫, 펄빈, 임병우. 노루궁뎅이 버섯 열수추출물의 항산화 활성과 항염증 효능 평가. 한국약용 작물학회지, 21: 112-117, 2013.

김영은, 박세연, 최태부. 청미래 덩굴 초임계 추출물의 멜라닌 생성억제 효과. 한국미용학회지, 20: 707-712, 2014. 김주덕, 김상진, 김한식, 박경환, 이화순, 진종언. 신화장품학. 동화기술, 파주, pp40-44, 2004. (光井武夫. 1997.) 이해준, 김환성, 박영종, 김중선, 문창종, 김종춘, 배춘식, 조성기, 김성호. 마우스에서 보중익기탕이 자외선 $\mathrm{B}$ 조사에 의한 표 피멜라닌세포 변화에 미치는 영향. 방사선방어학회지, 33: 87-91, 2008. 최병욱, 이봉호, 강기정, 이은석, 이남호. 해조류 및 생약의 Tyrosinase 억제활성 검색. 생약학회지, 29: 237-242, 1998. 홍기형, 김병용, 김혜경. 아위버섯(Pleurotus ferulea) 영양성분 분석. 한국식품과학회지, 36: 563-567, 2004. 


\section{中文摘要}

\section{猴头菌提取物抑制黑色素形成以及抗氧化功效}

全世銀 ${ }^{1}$, 黃婉珽 $^{2}$, 紅允喜 $^{2}$, 金美正 $^{3}$, 安恩淑 $^{4}$, 朴世蓮 $^{5 *}$

建国大學校生物工程科, 首尔, 韩国

${ }^{2}$ 同德女子大學校 保健科學大學院 香妆美容科, 首尔, 韩国

同德女子大學校 保健香妆學科，首尔，韩国

${ }^{4}$ 同德女子大學校药學科，首尔，韩国

${ }^{5}$ 同德女子大學校 应用化學科，首尔，韩国

目的: 探索猴头菌提取物对黑色素合成以及氧化应激调节的影响。方法: 采用 $95 \%$ 乙醇和蒸馏水对猴头菌进行提取, 乙醇提 取物再次采用蒸馏水和氯仿进行萃取。利用B16F1细胞测定黑色素合成量, 利用MTT assay方法来测定猴头菌对B16F1细胞 和HaCaT细胞的毒性。 $\beta$-Catenin/Tcf活性通过luciferase assay来测定。经TBHP处理后, 通过DCFDA表达程度来确认猴头菌 提取物的抗氧化功效。结果: Wnt信号通路配体Wnt3a的作用是增加 $\beta$-catenin的信号和黑色素的合成, 而猴头菌提取物降低 Wnt3a诱导的黑色素合成。猴头菌提取物抑制 $\beta$-catenin的活性，其作用呈剂量依赖性。此外，猴头菌提取物对氧化应激诱 导的角质形成细胞具有抗氧化效果。猴头菌提取物对研究中使用的黑色素瘤细胞和角质形成细胞的毒性明显不大。结论: 通过研究猴头菌提取物作为美白功效性以及抗氧化化妆品原料充分具有可行性。

关键词: Wnt/ß-catenin，猴头菌，提取物，黑色素瘤，抗氧化 
